\title{
Notas aproximativas sobre a política de saúde brasileira no contexto de crise do capital
}

\author{
Thaísa Simplício Carneiro MATIAS(1)
}

\author{
(1)Universidade Federal do Rio Grande do Norte - UFRN, Natal, RN, Brasil.
}

Recebido: 28 jan 2019 Aceito: 10 fev 2019

Autor de correspondência:

thaisasimplicio@hotmail.com

Conflito de interesses: Os autores declaram não haver nenhum interesse profissional ou pessoal que possa gerar conflito de interesses em relação a este manuscrito.

\section{Resumo}

O debate em torno da crise desencadeada nas últimas décadas no capitalismo financeirizado, articulado à reestruturação produtiva e ao ideário neoliberal, vem complexificando e está posto tanto para os sujeitos sociais, movimentos das diferentes políticas e segmentos sociais, como também na academia. Este trabalho buscou discutir as implicações da crise estrutural do capital para a política de saúde brasileira. O tema proposto é recorrente e de precípua relevância para a análise da particularidade na política de saúde e respectivas formas de resistência na perspectiva de fortalecer o projeto da classe trabalhadora. Metodologia: esta revisão parte das determinações teórico-políticas da tradição marxista. Resultados e Discussão: a crise estrutural do capital reafirma o caráter destrutivo das possibilidades civilizatórias e barbarização da vida social. Inúmeras mudanças nas esferas de produção e reprodução sociais desde então implicou aos países a reconfiguração do Estado, mediante política de ajustes contrarreformas. A suposta crise fiscal do Estado passou a ser o argumento de defesa neoliberal ao corte de gastos sociais, escondendo as intenções de diminuição dos custos com a força de trabalho e o redirecionamento do fundo público para atender em maior escala as demandas do grande capital. Estas análises tonam-se de extrema relevância ao nos remetermos à política de saúde brasileira que, conforme regulamentada na Constituição Federal de 1988 e na Lei Orgânica da Saúde significou um grande avanço no projeto da Reforma Sanitária Brasileira - RSB ao incorporar no tripé da Seguridade Social a saúde, juntamente com a assistência e previdência social. Destacamos dentre as polêmicas desde formulação do Sistema Único de Saúde - SUS a relação público-privado: havia uma proposta radical, de estatização integral e imediata de todas as instituições destinadas à saúde; entretanto, a que prevaleceu defendia a estatização progressiva do sistema de saúde. Nessa correlação de forças em confronto configurou um sistema dual (mix público-privado), uma das principais características do sistema de saúde brasileiro. Apesar dos avanços legais na referida política, é necessário reconhecer a contradição na materialização dos direitos sociais, os quais foram fortemente tensionados pela ofensiva neoliberal, culminando em retrocessos. A ênfase destas medidas de ajuste no setor nos chama, quando o Partido dos Trabalhadores assumiu a gestão federal a partir de 2002. Naquele contexto havia uma grande expectativa em retomar a agenda da 
RSB da década de 1980, fortalecendo a política de saúde dentro da perspectiva constitucional da seguridade social. Entretanto ocorreu a reafirmação das medidas privatistas no setor (com ênfase na focalização, na precarização, na terceirização dos recursos humanos e no subfinanciamento). Em face deste contexto, chamamos atenção para um novo projeto, intrinsecamente relacionado ao privatista: trata-se do projeto do SUS possível, defendido por antigas lideranças do movimento da RSB, mas flexibilizando os princípios políticoemancipatórios de sua racionalidade, a fim de modernizar o SUS, partindo da estratégia de refuncionalizar os princípios do SUS (em sintonia com as necessidades da contrarreforma); do transformismo das lideranças do movimento da RSB; e disseminação da ideia de que é inviável a implementação do SUS constitucional. Perfilando a política de saúde na atual conjuntura, chamamos atenção para a focalização dos gastos nos setores de extrema pobreza, como também a descentralização da gestão da esfera federal para estados e municípios, sem garantir a contrapartida necessária à execução das ações. Ao mesmo tempo, verificamos um deslocamento da prestação de bens e serviços públicos para o setor privado, através da participação de entidades não governamentais, filantrópicas, comunitárias e de empresas privadas. Neste caminho ganha destaque a Lei 9.637/1998, o Projeto de Lei Complementar - PLC $n^{\circ}$ 92/2007 que cria as fundações estatais de direito privado (FEDP) e a Lei 12.550/2011, que regulamenta a gestão dos hospitais universitários por meio das Empresas Brasileiras de Serviços Hospitalares - EBSERH. Entendemos que a implantação desses modelos de gestão os quais justificam não só deixam de cumprir seus objetivos de melhorias na atenção à saúde da população, como complexificam os problemas historicamente identificados no SUS e ferem a própria Constituição Federal vigente. O contexto de contradições e ataques ao SUS constitucional e defendido pelo movimento da RSB da década de 1980 tornaram ainda mais dramático na gestão do presidente interino Michel Temer intensificou o processo de privatizações, focalização das políticas sociais e do avanço do capital, mediante o ataque da universalidade do SUS e valorização da expansão dos planos privados de saúde. Neste caminho, destacamos também o perdão aos planos privados de saúde; o fim do Serviço Móvel de Urgência SAMU e dos programas Mais Médicos e Aqui Tem Farmácia Popular; não reconhecimento do Conselho Nacional de Saúde - CNS, ao convocar integrantes de instituições privadas para ouvir propostas para o setor; e extensão da Desvinculação das Receitas da União - DRU até 2023 e aprovação da Emenda Constitucional 95. O contexto sinaliza mais dramático neste início de mandato de Jair Bolsonaro, cujo discurso e projeto são explicitamente privatistas e com bandeiras de extrema direita. Considerações finais: este trabalho partiu da crítica da economia política para discutir a particularidade da política de saúde contemporânea, a qual avançou substancialmente no campo jurídico-formal, mas perpassou por contradições e contrarreformas. Por outro lado e como forma de resistência aos ataques à política de saúde, desde 2010 foi criada a Frente Nacional Contra a Privatização da Saúde - FNCPS, estratégia que agrega diversas 
entidades representativas de trabalhadores, grupos de pesquisa, movimentos sociais e partidos políticos na luta contra toda forma de privatização da política de saúde. Diante do exposto, entendemos que desde os governos petistas houve continuidade aos ajustes fiscais restringindo os recursos para as políticas sociais, permitindo o desenvolvimento de mecanismos compensatórios focalizados nas camadas mais pobres, sem alterar, portanto, a desigualdade social historicamente marcante no país. Torna-se de precípua relevância entender as modificações na composição e na condução das políticas sociais brasileiras no atual curso histórico, exigindo um estudo histórico-crítico de desenvolvimento da fase madura do capitalismo.

Descritores: Capitalismo; Parcerias Público-Privadas; Políticas Públicas de Saúde. 